\title{
Distinct climate change synchronous with Heinrich event one, recorded by stable oxygen and carbon isotopic compositions in stalagmites from China
}

\author{
Houyun Zhou ${ }^{\mathrm{a}, *}$, Jianxin Zhao ${ }^{\mathrm{b}}$, Yuexing Feng ${ }^{\mathrm{b}}$, Michael K. Gagan ${ }^{\mathrm{c}}$, Guoqing Zhou ${ }^{\mathrm{d}}$, Jun Yan ${ }^{\mathrm{e}}$ \\ ${ }^{a}$ Guangzhou Institute of Geochemistry, Chinese Academy of Sciences, Wushan, Guangzhou 510640, P. R. China \\ ${ }^{\mathrm{b}}$ Radiogenic Isotope Laboratory, Centre for Microscopy and Microanalysis, University of Queensland, Brisbane, Qld 4072, Australia \\ ${ }^{\mathrm{c}}$ Research School of Earth Sciences, The Australian National University, Canberra, ACT 0200, Australia \\ ${ }^{\mathrm{d}}$ Department of Earth Sciences, Nanjing University, Nanjing 210093, China \\ e School of Resources and Environmental Engineering, Hefei University of Technology, Hefei 230009, China
}

Received 7 January 2007

Available online 26 December 2007

\begin{abstract}
Uranium-series dating of oxygen and carbon isotope records for stalagmite SJ3 collected in Songjia Cave, central China, shows significant variation in past climate and environment during the period 20-10 ka. Stalagmite SJ3 is located more than $1000 \mathrm{~km}$ inland of the coastal Hulu Cave in East China and more than $700 \mathrm{~km}$ north of the Dongge Cave in Southwest China and, despite minor differences, displays a clear firstorder similarity with the Hulu and Dongge records. The coldest climatic phase since the Last Glacial Maximum, which is associated with the Heinrich Event 1 in the North Atlantic region, was clearly recorded in SJ3 between 17.6 and 14.5 ka, in good agreement in timing, duration and extent with the records from Hulu and Dongge caves and the Greenland ice core. The results indicate that there have been synchronous and significant climatic changes across monsoonal China and strong teleconnections between the North Atlantic and East Asia regions during the period 20-10 ka. This is much different from the Holocene Optimum which shows a time shift of more than several thousands years from southeast coastal to inland China. It is likely that temperature change at northern high latitudes during glacial periods exerts stronger influence on the Asian summer monsoon relative to insolation and appears to be capable of perturbing large-scale atmospheric/oceanic circulation patterns in the Northern Hemisphere and thus monsoonal rainfall and paleovegetation in East Asia. Climatic signals in the North Atlantic region propagate rapidly to East Asia during glacial periods by influencing the winter land-sea temperature contrast in the East Asian monsoon region.

(C) 2007 University of Washington. All rights reserved.
\end{abstract}

Keywords: Speleothem; $\delta^{18} \mathrm{O} ; \delta^{13} \mathrm{C}$; The H1 cold phase; Synchronicity; East Asia; Teleconnection; Atmospheric circulation

\section{Introduction}

Global change since the last glacial maximum (LGM) is important because it displays the most recent turnover of the climate and environment on Earth (Jouzel et al., 1987; Martinson et al., 1987; Thompson et al., 1997; Liu and Ding, 1998). Up to present, however, some issues about climatic and environmental change since the LGM, such as the timing, duration and extent of some climatic extremes are not yet thoroughly addressed. For example, sea surface temperature (SST) reconstruction by the CLIMAP Project Members (1976) indicated that SST increased by $\sim 2{ }^{\circ} \mathrm{C}$ over most of the middle latitude Pacific Ocean since

\footnotetext{
* Corresponding author. Fax: +86 2085290130

E-mail address: hyzhou@gig.ac.cn (H. Zhou).
}

the LGM, while for the subtropical region, SST in the LGM was similar to modern SST. Based on coral-derived SST, however, Beck et al. (1997) suggested that last glacial SST in the tropical oceans might be up to $6{ }^{\circ} \mathrm{C}$ cooler than in the Holocene. With the application of a variety of transfer function techniques, Kucera et al. (2005) reconstructed the SSTs of the Atlantic and Pacific Oceans using assemblages of planktonic foraminifera and found that the LGM SSTs in the Okinawa Trough were more than $1^{\circ} \mathrm{C}$ higher than present. However, this is not consistent with most other SST reconstructions in this region (Ijiri et al., 2005; Zhou et al., 2007).

In continental East Asia, many geological archives indicate remarkable climatic changes since the LGM (Thompson et al., 1997; Liu and Ding, 1998; Wang et al., 2001). For example, the stable oxygen isotopic composition $\left(\delta^{18} \mathrm{O}\right)$ of a speleothem 
from Hulu Cave in East China (Fig. 1) suggest significant variations in the intensity of the East Asian summer monsoon, and a parallelism between monsoon variations and temperature changes in northern high latitudes (Grootes et al., 1993; Stuiver et al., 1995). This was supported by Zhao et al. (2003) using the oxygen and carbon isotopic compositions $\left(\delta^{13} \mathrm{C}\right)$ of another stalagmite collected from the same cave, and by Yuan et al. (2004) and Dykoski et al. (2005) using the speleothem $\delta^{18} \mathrm{O}$ record from Dongge Cave in Southwest China. The speleothem $\delta^{18} \mathrm{O}$ record from Heshang Cave in Central China (Hu et al., 2005; Fig. 1), however, seems to be a little different although it is generally parallel with the Hulu $\delta^{18} \mathrm{O}$ records (Wang et al., 2001; Zhao et al., 2003). For example, the Younger Dryas (YD) cooling event and the transitions from the LGM to the succeeding cold climatic phase (associated with the iceberg discharge event $\mathrm{H} 1$ recorded in the North Atlantic sediments (Heinrich, 1988), referred to as the $\mathrm{H} 1$ cold phase hereinafter) are not clear in this record compared with what recorded in the Hulu and Dongge caves (Wang et al., 2001; Yuan et al., 2004; Dykoski et al., 2005).

Marine records from the West Pacific seem to suggest a latitudinal shift in the last deglaciation timing (Visser et al., 2003; Ijiri et al., 2005; Zhou et al., 2007). Both geological data and numerical modeling indicate that the Holocene optimum, the warmest period since the LGM (Shi et al., 1992), as defined by peak East Asian summer monsoon precipitation, was asynchronous in central and eastern China (An et al., 2000; He et al., 2004). Then, does the difference between the speleothem $\delta^{18} \mathrm{O}$ records from Heshang Cave and the Hulu and Dongge caves imply that some cold climatic extremes since the LGM, such as the $\mathrm{H} 1$ cold phase, are also asynchronous in East Asia? Do these events show any difference in timing, duration or extent of climatic change in central and eastern China?

In this paper, we report the $\delta^{18} \mathrm{O}$ and $\delta^{13} \mathrm{C}$ records of a stalagmite (SJ3) collected from Nuoshuihe in Northeast
Sichuan, Central China. This site lies northwest of Heshang Cave, more than $1000 \mathrm{~km}$ west of Hulu Cave and $700 \mathrm{~km}$ north of Dongge Cave. Thus it is closer to the northwest boundary of the summer monsoon (Fig. 1). The $\delta^{18} \mathrm{O}$ and $\delta^{13} \mathrm{C}$ records for SJ3 show a distinct climatic event synchronous with the $\mathrm{H} 1$ cold phase, which is similar in timing, duration and extent to the event recorded in the Hulu and Dongge caves (Wang et al., 2001; Yuan et al., 2004), suggesting a continent-wide synchronicity of this coldest climatic phase since the LGM.

\section{Geological setting}

Stalagmite SJ3 was sampled from Songjia Cave in northeastern Sichuan, central China $\left(107^{\circ} 10^{\prime} 45^{\prime \prime} \mathrm{E}, 32^{\circ} 24^{\prime} 46^{\prime \prime} \mathrm{N}\right)$ (Fig. 1). The cave lies in the south flank of the Qinling Mountain. To its east flows the Nuoshuihe River which eventually runs into the Changjiang River. Songjia Cave has two entrances on the steep slope on the west of the Nuoshuihe River, $\sim 35 \mathrm{~m}$ apart and one with an elevation of $\sim 680 \mathrm{~m}$ and the other $\sim 687 \mathrm{~m}$. The cave is $254 \mathrm{~m}$ long and extends generally westwards (Cao and Yang, 2005). It was opened to tourism in 1990s and theretofore it was explored by local people at intervals.

Songjia Cave is hosted in the Late Permian carbonatite with an age of 257-250 ma and there is no non-carbonate rock type found around the cave. The carbonatite consists of middle to thick dark grey flint limestone, limestone and dolomitic limestone (Bureau of Geology and Mineral Resources of Sichuan Province, 1991). The overlying soil layer on the limestone capping the cave is thin (usually less than $30 \mathrm{~cm}$ ) or absent in places. Local vegetation consists mainly of arbor including pine, cypress and some deciduous broadleaf species.

Qinling Mountain is an important climatic boundary in China with north sub-tropical climate to its north and middle sub-tropical climate to its south. The study site is significantly influenced by both summer and winter monsoons (Fig. 1). The

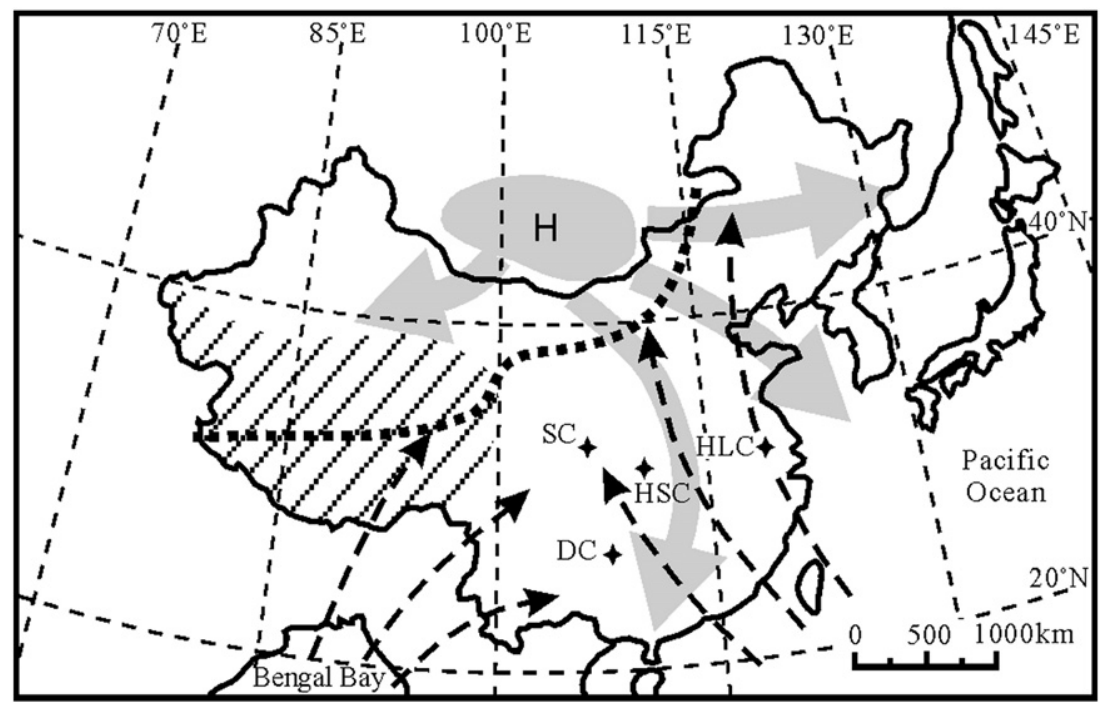

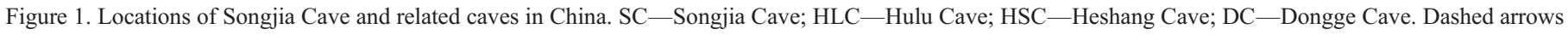

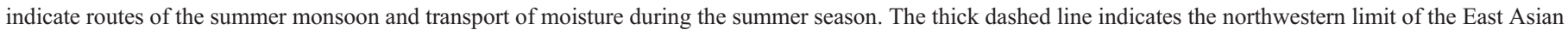

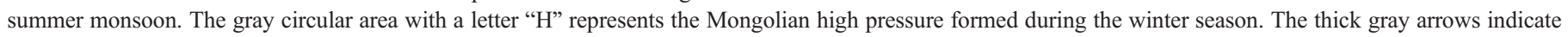
routes of the winter monsoon. The hatched area is the Qinghai-Tibet Plateau. 
summer season is characterized by higher temperature and more precipitation, while during the winter season, dust activity is intense. Annual mean temperature is $\sim 15{ }^{\circ} \mathrm{C}$ and annual mean precipitation is between 1000 and $1200 \mathrm{~mm}$ (Sinomaps Press, 1984). Most of the precipitation falls in the summer half year.

\section{Sample description and methods}

\section{Sample description}

Stalagmite SJ3 is $12.6-\mathrm{cm}$ long and, like most stalagmites, it is thicker at the base than at the top. The stalagmite was sectioned longitudinally along its growth axis to expose its stratigraphy and a clear growth hiatus at $\sim 84 \mathrm{~mm}$ below its top. In this paper, we report the $\delta^{18} \mathrm{O}$ and $\delta^{13} \mathrm{C}$ records for the upper part. Growth layer is clear on the cut surface and displays a relatively flat top of SJ3 (Fig. 2). The top $6 \mathrm{~mm}$ of SJ3 is dirty with abundant detrital materials. Microscopic examination reveals several micro-growth hiatuses in this dirty section.

\section{${ }^{238} U-{ }^{234} U-{ }^{230}$ Th Dating}

Seven sub-samples for U-series dating were obtained from the cleaned cut surface using a micro-drill. ${ }^{230} \mathrm{Th}$ dates were determined after $\mathrm{U}$ and $\mathrm{Th}$ were separated following the method described in Zhao et al. (2001). ${ }^{230}$ Th age determination was conducted in the Radiogenic Isotope Laboratory, the University of Queensland using a VG Sector-54 thermal ionization mass spectrometer (TIMS). ${ }^{230} \mathrm{Th}$ ages are calculated using Isoplot Excel Version. The detrital U-Th correction is applied assuming the detrital component $\mathrm{Th} / \mathrm{U}=3.8 \pm 1.9$ (average crustal value) (equivalent to ${ }^{230} \mathrm{Th} /{ }^{232} \mathrm{Th} \approx 0.83 \pm 0.41$ ), and ${ }^{238} \mathrm{U}$, ${ }^{234} \mathrm{U},{ }^{232} \mathrm{Th}$ and ${ }^{230} \mathrm{Th}$ are in secular equilibrium. The detrital correction results in a large age error magnification for samples with low ${ }^{230} \mathrm{Th} /{ }^{232} \mathrm{Th}$ ratios.

\section{Stable isotopes}

Sub-samples of stalagmite SJ3 were collected for $\delta^{18} \mathrm{O}$ and $\delta^{13} \mathrm{C}$ analysis, as follows. First, a thin slab (about $5 \mathrm{~mm}$ wide and 3-4 mm thick) was taken from the central growth axis of SJ3. Then the slab was ultrasonically cleaned three times in deionized water. Sub-samples were then manually scraped from the upper surface of SJ3 with a scalpel. The sampling interval is $\sim 100 \mu \mathrm{m}$. Two samples were analyzed out of 10 collected from every millimeter, at the start and middle of each millimeter, and a total of 167 sub-samples were analyzed. Sub-samples for the Hendy Test (Hendy and Wilson, 1968; Hendy, 1971; Schwarcz, 1986) were drilled on the cleaned cut surface along three growth layers using a micro-drill. The three layers are at depths of 27 , 53 and $79 \mathrm{~mm}$ from the top of SJ3.

$\delta^{18} \mathrm{O}$ and $\delta^{13} \mathrm{C}$ in stalagmite $\mathrm{SJ} 3$ were measured using an automated individual-carbonate reaction (Kiel) device coupled with a Finnigan MAT 251 mass spectrometer at The Australian National University. Each powdered sample $(\sim 0.2 \mathrm{mg}$ of carbonate) was reacted with $103 \% \mathrm{H}_{3} \mathrm{PO}_{4}$ at $90{ }^{\circ} \mathrm{C}$ to liberate sufficient $\mathrm{CO}_{2}$ for isotopic analysis. All isotope ratios are

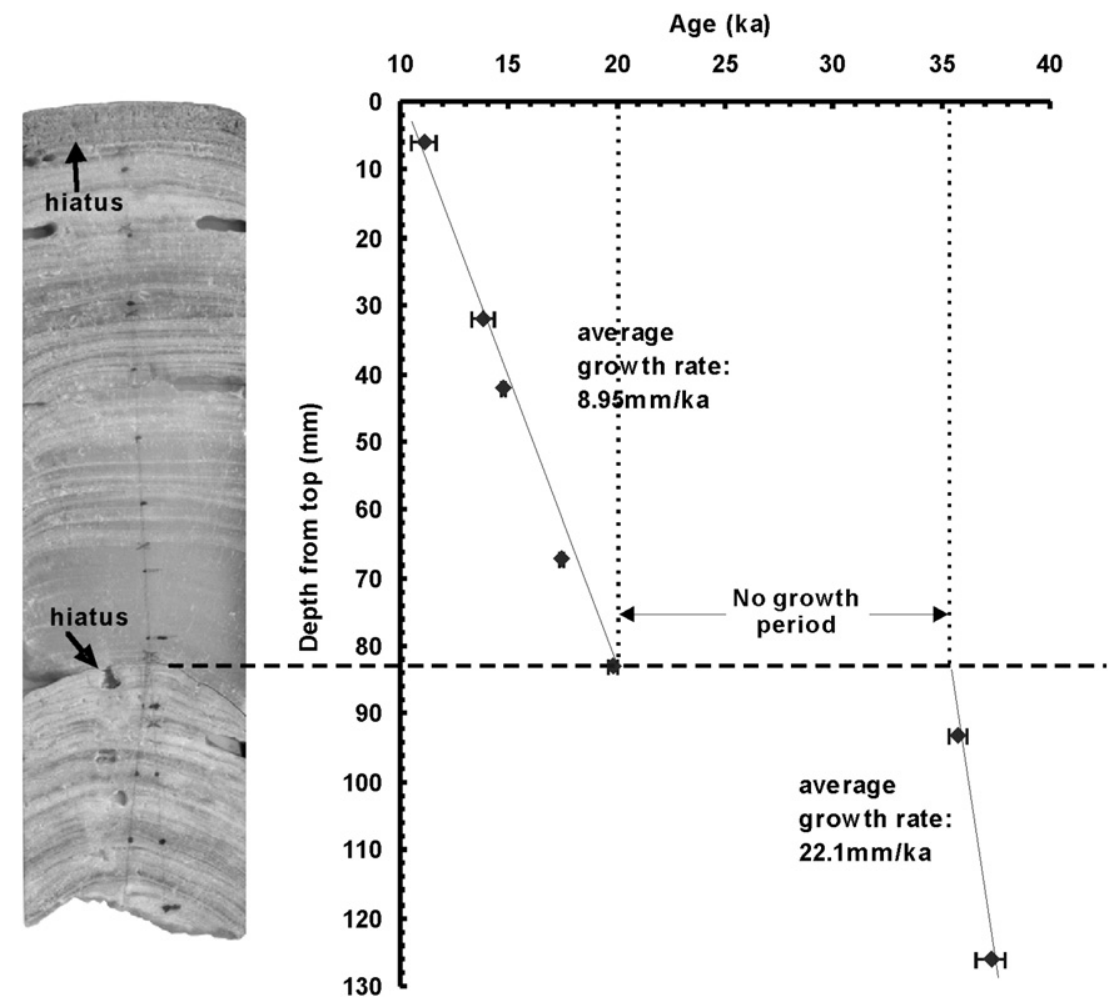

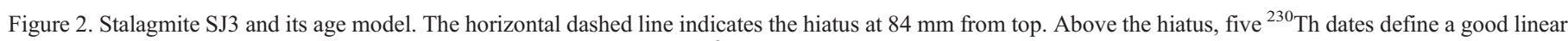

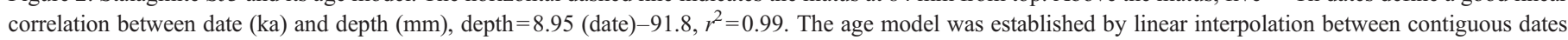
according to depth below the top of SJ3. Horizontal bars indicate age error for each age determination. 
reported in permil (\%o) deviations relative to the Vienna Peedee Belemnite (VPDB) standard in the conventional manner. The results have been normalised on the VPDB scale such that the NBS-19 calcite standard yields $\delta^{18} \mathrm{O}_{\mathrm{VPDB}}(-2.20 \%)$ and $\delta^{13} \mathrm{C}_{\mathrm{VPDB}}\left(+1.95 \%\right.$ ) and NBS-18 yields $\delta^{18} \mathrm{O}_{\mathrm{VPDB}}(-23.0 \%$ ) and $\delta^{13} \mathrm{C}_{\mathrm{VPDB}}(-5.0 \%$ ). The standard deviation $(1 \sigma)$ for replicate measurements on NBS-19 $(n=42)$ is $\pm 0.09 \%$ for $\delta^{18} \mathrm{O}$ and $\pm 0.03 \%$ for $\delta^{13} \mathrm{C}$.

\section{Results}

\section{Dates and Age model}

Seven TIMS ${ }^{230} \mathrm{Th}$ dates for SJ3 are listed in Table 1, indicating that SJ3 developed from 38 to $10 \mathrm{ka}$. A plot of age versus depth is shown in Figure 2, in which the growth hiatus at $84 \mathrm{~mm}$ in depth is clearly indicated. Above the hiatus, the stalagmite grew at a semi-constant rate of $\sim 9 \mathrm{~mm} / \mathrm{ka}$. The two dates below the hiatus define an average growth rate of $\sim 22 \mathrm{~mm} / \mathrm{ka}$ (Fig. 2). If constant growth rates of $9 \mathrm{~mm}$ and $22 \mathrm{~mm}$ per ka are assumed for the upper and lower sections of the stalagmite, respectively, the hiatus at $84 \mathrm{~mm}$ would represent a non-growth period between 35 and $20 \mathrm{ka}$ (Fig. 2). Therefore, it can be assumed that SJ3 developed in two periods, (38-35) ka in marine isotope stage (MIS) 3 and (20-10) ka in MIS 2. An age model for SJ3 was established by linear interpolation between contiguous dates according to depth from top (Fig. 2).

\section{Hendy Test}

It is usually believed that speleothem $\delta^{18} \mathrm{O}$ and $\delta^{13} \mathrm{C}$ records are appropriate for investigation of past climate and environment only when carbonate is precipitated in isotopic equilibrium with its corresponding drip water. Some criteria such as the Hendy Test (Hendy and Wilson, 1968; Hendy, 1971; Schwarcz, 1986) and replication of contemporaneous records (Dorale et al., 1998; Wang et al., 2001) were proposed to check the equilibrium precipitation of speleothem carbonate and were followed in numerous publications. Although this test was challenged by Fleitmann et al. (2004) and Webster et al. (2007) recently, we did the Hendy Test along three growth layers of SJ3.

The Hendy Test has two criteria that, (1) along a single growth line $\delta^{18} \mathrm{O}$ shows little variation while $\delta^{13} \mathrm{C}$ may vary irregularly, and (2) $\delta^{18} \mathrm{O}$ and $\delta^{13} \mathrm{C}$ values along a single growth line not be positively correlated (Hendy and Wilson, 1968;
Hendy, 1971; Schwarcz, 1986; Gascoyne, 1992). Figure 3 displays the result of the Hendy Test carried out along three growth layers at depths of 27,53 and $79 \mathrm{~mm}$. It is clear that for any single layer, $\delta^{18} \mathrm{O}$ does not show significant variation and is not positively correlated with the $\delta^{13} \mathrm{C}$ of the same layer (Fig. 3). The $\delta^{18} \mathrm{O}$ or $\delta^{13} \mathrm{C}$ change along any single layer is no more than $0.4 \%$ (Fig. 3), which is much smaller than the $\delta^{18} \mathrm{O}$ or $\delta^{13} \mathrm{C}$ variation along the growth axis of SJ3 (at least $4 \%$, see the next sections). Therefore, the carbonate in SJ3 is assumed to be deposited in isotopic equilibrium with the parent solution and the $\delta^{18} \mathrm{O}$ and $\delta^{13} \mathrm{C}$ records for $\mathrm{SJ} 3$ should be appropriate for interpretation of past climate and environment.

If the calcite in $\mathrm{SJ} 3$ is indeed deposited under isotopic equilibrium, the $\mathrm{SJ} 3 \delta^{18} \mathrm{O}$ record should be a function of cave temperature (reflecting annual mean surface temperature (Wigley and Brown, 1976)) and the oxygen isotopic composition of cave drip water, which is closely related to $\delta^{18} \mathrm{O}$ of local precipitation and therefore to surface climate (Rozanski, 1985; Winograd et al., 1985). In the East Asian summer monsoon regime, the temperature effect on the $\delta^{18} \mathrm{O}$ of precipitation seems to be weak (Rozanski et al., 1992, 1993; Araguas-Araguas and Froehlich, 1998) and offset by the fractionation between water and calcite (Kim and O'Neil, 1997), making the speleothem $\delta^{18} \mathrm{O}$ record an appropriate proxy for rainfall amount and summer monsoon intensity (Wang et al., 2001; Yuan et al., 2004). Thus in the following discussion, we interpret the SJ3 $\delta^{18} \mathrm{O}$ record in terms of variation in the Asian summer monsoon.

\section{Oxygen and carbon isotopes}

The $\delta^{18} \mathrm{O}$ along the growth axis of SJ3 is shown in Figure 4. It fluctuates between -6.5 and $-11.6 \%$ with an average of $-8.99 \%$. The highest value $(-6.5 \%$ ) occurred between 16.3 and $16.6 \mathrm{ka}$ while the lowest $(-11.6 \%$ o) is at $\sim 11.2 \mathrm{ka}$. It is apparent that the $\delta^{18} \mathrm{O}$ for SJ3 is on average much lower than the Hulu record (Fig. 4b) which varies between -4.0 and $-8.8 \%$. This is consistent with previous studies which revealed that over the continental China, contemporaneous speleothem $\delta^{18} \mathrm{O}$ generally decreases from south to north and from east to west (Wang et al., 2001; Yuan et al., 2004; Tan and Cai, 2005; Hu et al., 2005; Johnson et al., 2006; Shao et al., 2006). It is also in accordance with the $\delta^{18} \mathrm{O}$ distribution of modern precipitation (Zhang and Yao, 1998; Zhou, 2002), which may be related to vapor source (Johnson et al., 2006) and the continentality effect (Dansgaard, 1964).

Table 1

TIMS-U series isotopic results and ages for stalagmite SJ3 from Songjia Cave

\begin{tabular}{|c|c|c|c|c|c|c|c|c|c|c|c|c|c|c|}
\hline $\begin{array}{l}\text { Sample } \\
\text { ID }\end{array}$ & $\begin{array}{l}\text { Depth from } \\
\text { top (mm) }\end{array}$ & $\begin{array}{l}\text { U } \\
\text { (ppm) }\end{array}$ & $\pm 2 \sigma$ & $\begin{array}{l}{ }^{232} \mathrm{Th} \\
(\mathrm{ppb})\end{array}$ & $\pm 2 \sigma$ & ${ }^{230} \mathrm{Th} /{ }^{232} \mathrm{Th}$ & ${ }^{230} \mathrm{Th} /{ }^{238} \mathrm{U}$ & $\pm 2 \sigma$ & ${ }^{234} U /{ }^{238} U$ & $\pm 2 \sigma$ & $\begin{array}{l}\text { Corrected }{ }^{230} \mathrm{Th} \\
\text { Age }(\mathrm{kaBP})\end{array}$ & $\pm 2 \sigma$ & $\begin{array}{l}\text { Corrected initial } \\
\left({ }^{234} \mathrm{U} /{ }^{238} \mathrm{U}\right)\end{array}$ & $\pm 2 \sigma$ \\
\hline SJ3-006 & 7 & 0.2705 & 0.0002 & 19.9 & 0.1 & 8.0 & 0.1947 & 0.0018 & 1.8044 & 0.0038 & 11.12 & 0.56 & 1.8471 & 0.0095 \\
\hline SJ3-032 & 32 & 0.3928 & 0.0003 & 26.5 & 0.1 & 10.4 & 0.2316 & 0.0028 & 1.7865 & 0.0024 & 13.85 & 0.53 & 1.8520 & 0.0093 \\
\hline SJ3-042 & 42 & 0.4014 & 0.0002 & 1.4 & 0.0 & 205.2 & 0.2275 & 0.0019 & 1.7709 & 0.0024 & 14.76 & 0.13 & 1.8332 & 0.0081 \\
\hline SJ3-067 & 67 & 0.4583 & 0.0004 & 2.5 & 0.0 & 149.0 & 0.2706 & 0.0014 & 1.7971 & 0.0044 & 17.45 & 0.12 & 1.8046 & 0.0025 \\
\hline SJ3-083 & 83 & 0.3571 & 0.0005 & 3.1 & 0.0 & 103.7 & 0.2975 & 0.0019 & 1.7518 & 0.0038 & 19.83 & 0.16 & 1.8388 & 0.0045 \\
\hline SJ3-093 & 93 & 0.2344 & 0.0002 & 9.1 & 0.1 & 38.8 & 0.4985 & 0.0040 & 1.7157 & 0.0035 & 35.77 & 0.43 & 1.7971 & 0.0040 \\
\hline SJ3-126 & 126 & 0.2309 & 0.0001 & 23.2 & 0.1 & 16.2 & 0.5372 & 0.0024 & 1.7467 & 0.0018 & 37.26 & 0.65 & 1.8005 & 0.0056 \\
\hline
\end{tabular}



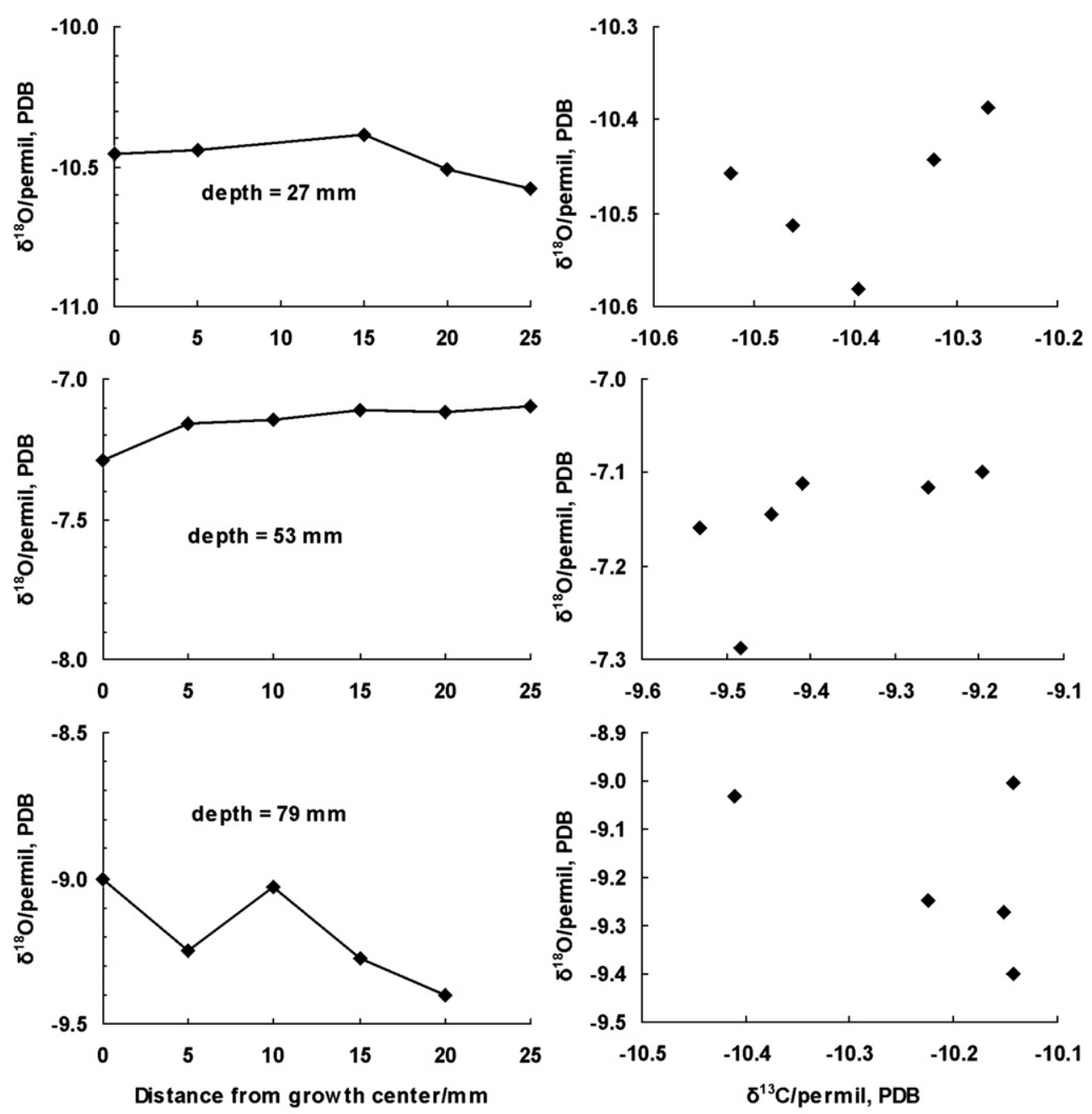

a

b

Figure 3. Hendy tests conducted along three growth layers of $\mathrm{SJ} 3$ at depths of 27,53 and $79 \mathrm{~mm}$. The $\delta^{18} \mathrm{O}$ and $\delta^{13} \mathrm{C}$ within individual layer vary by less than $0.5 \%$ (a) and there is no positive correlation between $\delta^{18} \mathrm{O}$ and $\delta^{13} \mathrm{C}(\mathrm{b})$, indicating no significant kinetic effects when SJ3 calcite was deposited.

The $\delta^{13} \mathrm{C}$ record is also displayed in Figure 4. It fluctuates between -3.7 and $-11.6 \%$ with an average of $-9.99 \%$. The highest values occur in the top dirty part of SJ3, while the three lowest values occur at 11.1, 12.0 and $14.0 \mathrm{ka}$. Generally, the $\delta^{13} \mathrm{C}$ record is parallel with the $\delta^{18} \mathrm{O}$ record except during the dirty part at the top where the $\delta^{13} \mathrm{C}$ values are more than $4 \%$ higher relative to the rest of SJ3 (Fig. 4d).

Variation of $\delta^{13} \mathrm{C}$ in speleothems has been used to infer the relative proportions of the $\mathrm{C}_{3^{-}}$-versus $\mathrm{C}_{4}$-plants (Holmgren et al., 1995; Dorale et al., 1998), changes in ecosystem productivity that controls soil air $\mathrm{PCO}_{2}$ and determines the amount of isotopically light organic matter released to the soil in areas where $\mathrm{C}_{4}$-type vegetation is not present (Genty et al., 2003), changes in the $\delta^{13} \mathrm{C}$ value of atmospheric $\mathrm{CO}_{2}$ (Baskaran and Krishnamurthy, 1993), and changes in water-rock interactions (Baker et al., 1997; McDermott, 2004). Excepting the $\delta^{13} \mathrm{C}$ value of atmospheric $\mathrm{CO}_{2}$, whose variations since the LGM remains poorly known, all the other three mechanisms might be applicable for interpreting the $\delta^{13} \mathrm{C}$ record for SJ3, with higher values occurring during cold-dry periods (such as the $\mathrm{H} 1$ cold phase) and lower values during warm-humid periods (Fig. 4d). Warm-humid climate may favor $\mathrm{C}_{3}$-type vegetation and promote bio-productivity. It may also lead to stronger waterrock interactions because of higher $p \mathrm{CO}_{2}$ of groundwater due to higher soil $p \mathrm{CO}_{2}$, which results from more intensive bioactivity and respiration and organic decomposition in soil (Spötl et al., 2005). It may be argued that under warm-humid climate karstic groundwater would be more dynamic and have a relatively short residence time, leading to a less water-rock interaction (Banner et al., 1996). However, this is the opposite to what indicated by the strontium geochemistry of SJ3 (Zhou et al., in preparation). No matter which mechanism is dominant, the lower values in the $\mathrm{SJ} 3 \delta^{13} \mathrm{C}$ record correspond to stronger summer monsoon and vice versa. Therefore the $\mathrm{SJ} 3 \delta^{13} \mathrm{C}$ record can also serve as a summer monsoon proxy.

The $\delta^{13} \mathrm{C}$ and $\delta^{18} \mathrm{O}$ values for the top dirty part of SJ3 are notable heavy. Especially the $\delta^{13} \mathrm{C}$ values are 5-6 \%o heavier than the average of the whole record (Fig. 4). As mentioned before, microscopic examination indicates several hiatuses and detrital grains in this part. Therefore we speculate that this dirty 


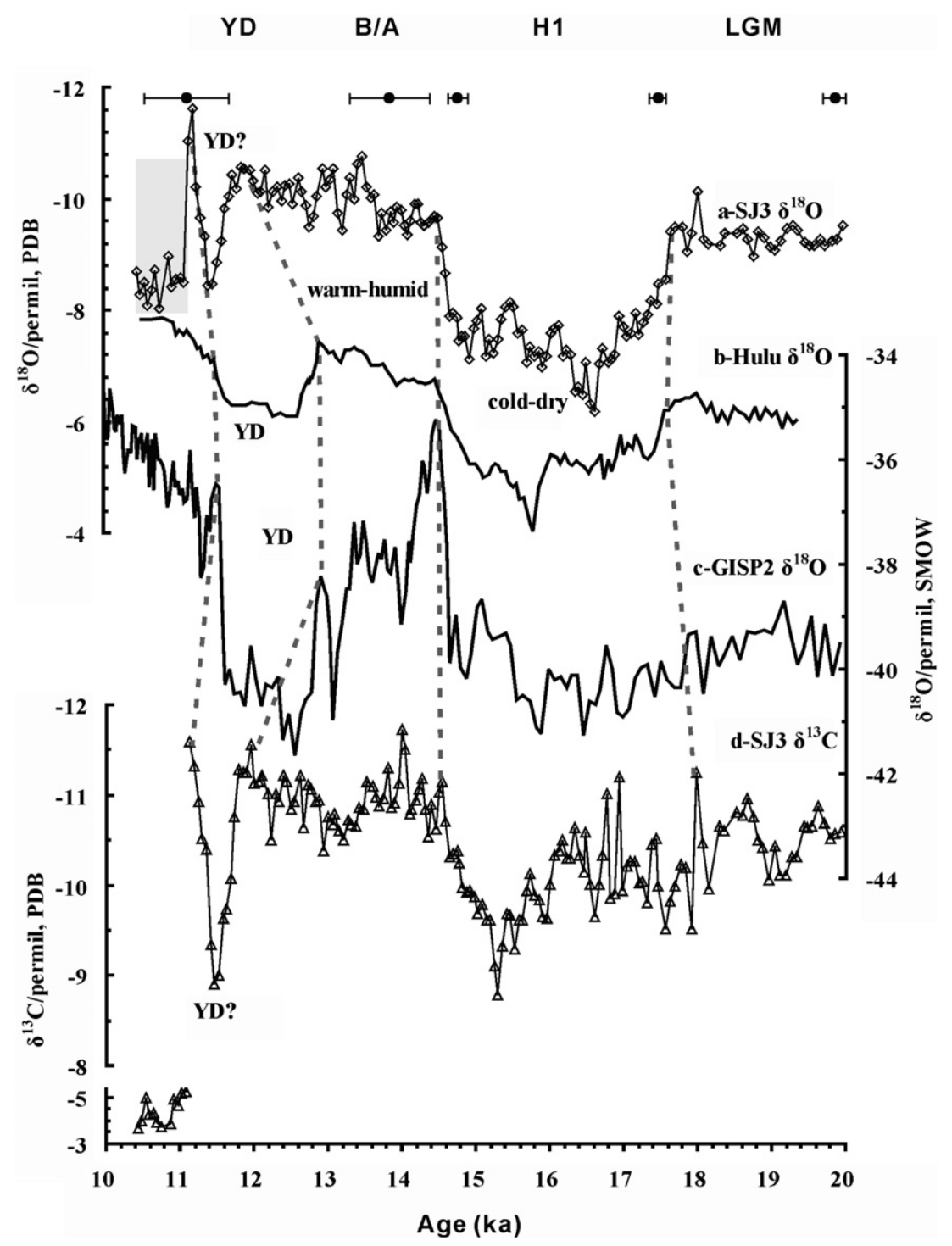

Figure 4. Comparison of stable isotope records for SJ3 (a, d), PD from Hulu Cave (b) (Wang et al., 2001), and the GISP2 ice core from Greenland (c) (Grootes et al.,

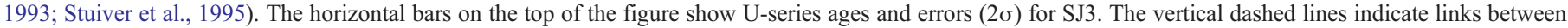
these records. The gray rectangle indicates the dirty top of SJ3 where calcite may not be deposited under isotopic equilibrium. The SJ3 $\delta^{18} \mathrm{O}$ record is apparently lower than the Hulu record. LGM: the last glacial maximum; H1: the cold climatic phase associated with the Heinrich event one; B/A: the Bølling-Allerød warm period; YD: the Younger Dryas cooling event. The YD event is less chronologically constrained in SJ3, probably resulting in the apparent difference in timing and duration of this event between the three $\delta^{18} \mathrm{O}$ records (SJ3, Hulu, GISP2).

part may have developed after the flow path for SJ3 was changed and when SJ3 was occasionally fed by dripwater during rainfall extremes. Calcite in this part may not be deposited under isotopic equilibrium, leading to higher $\delta^{13} \mathrm{C}$ and $\delta^{18} \mathrm{O}$ values.

\section{Discussion}

The $\delta^{18} \mathrm{O}$ record for SJ3 displays significant variations since the LGM, which is similar to the Hulu record from East China (Wang et al., 2001) and the GISP2 $\delta^{18} \mathrm{O}$ record from northern high latitude (Grootes et al., 1993; Stuiver et al., 1995) (Figs. $4 \mathrm{a}-\mathrm{c}$ ). The important climatic phases since the LGM, including the LGM, the coldest $\mathrm{H} 1$ phase, the Bølling-Allerød $(\mathrm{B} / \mathrm{A})$ warm period and the cooling YD event all are archived in these paleoclimatic records from East and Central China (Fig. 4) though the YD event recorded by SJ3 is different from that recorded by the Hulu speleothem (Wang et al., 2001) and the GISP2 ice core (Grootes et al., 1993; Stuiver et al., 1995) (Fig. 4). The YD event seems to commence much later and last a shorter time period in Central China than in East China and northern high latitude, but the ending of this event, including its timing and sharpness, seems to be in agreement among these records (Fig. 4). A possible cause for this apparent difference may be the scarcity of the dates for SJ3 around the YD event; more dating should be carried out on SJ3 in the future. In any case, the $\mathrm{SJ} 3 \delta^{18} \mathrm{O}$ record shows fluctuations generally parallel with the Hulu and GISP2 $\delta^{18} \mathrm{O}$ records (Fig. 4). This is somewhat different from the Heshang $\delta^{18} \mathrm{O}$ record, which does not show clearly the YD cooling event and the transition from the LGM into the H1 cold phase (Hu et al., 2005). 
The similarity among the $\delta^{18} \mathrm{O}$ records from Songjia Cave in Central China, Hulu Cave in East China and GISP2 ice core from northern high latitude is further supported by the $\mathrm{SJ} 3 \delta^{13} \mathrm{C}$ record (Fig. 4d). This record also indicates all the important climatic phases since the LGM and displays a parallelism to the three $\delta^{18} \mathrm{O}$ records (Figs. $4 \mathrm{a}-\mathrm{c}$ ).

The most prominent feature of the $\mathrm{SJ} 3 \delta^{18} \mathrm{O}$ record is be the H1 cold phase after the LGM (Fig. 5a). This event has clear boundaries in $\mathrm{SJ} 3$, starting from $\sim 17.6 \mathrm{ka}$ and ending at $\sim 14.5 \mathrm{ka}$, which is consistent with what is recorded in the Hulu and Dongge caves (Figs. 5b-c; Wang et al., 2001; Yuan et al., 2004; Dykoski et al., 2005). The start of this event in the Heshang record is not unambiguous and there are two possible correlations for it (Fig. 5d; Hu et al., 2005), different from what illustrated by the Hulu and Songjia records (Figs. 5a-b). A most probable cause for this may be that unlike the three stalagmites SJ3 (from Songjia Cave in central China), PD (from Hulu Cave in East China) and D4 (from Dongge Cave in Southwest China) which displayed relatively constant growth rates during the period between 20 and 10 ka (Fig. 2; Wang et al., 2001; Yuan et al., 2004; Dykoski et al., 2005), the growth rate for stalagmite HS-2 from Heshang Cave changed significantly since the LGM (Hu et al., 2005). A similar explanation may be applicable for the ambiguity of the YD cooling event in the Heshang record (Fig. 5d). Therefore, the Heshang record may need more dates to precisely constrain some important climatic events such as the YD cooling event and the H1 cold phase.

The transitions into and out of the $\mathrm{H} 1$ cold phase are similar among the three speleothem $\delta^{18} \mathrm{O}$ records from the Hulu, Dongge and Songjia caves (Figs. 5a-c). For example, in the SJ3 $\delta^{18} \mathrm{O}$ record, the transition from the LGM into the $\mathrm{H} 1$ cold phase took place within $200 \mathrm{yr}$ starting from $17.6 \mathrm{ka}$, which is almost identical to what revealed by the Hulu record (Figs. 5a-b). The transition from the $\mathrm{H} 1$ cold phase to the $\mathrm{B} / \mathrm{A}$ warm period is sharp and synchronous in all the three records, but it appears faster in the $\mathrm{SJ} 3$ record. For example, the $\mathrm{SJ} 3 \delta^{18} \mathrm{O}$ record

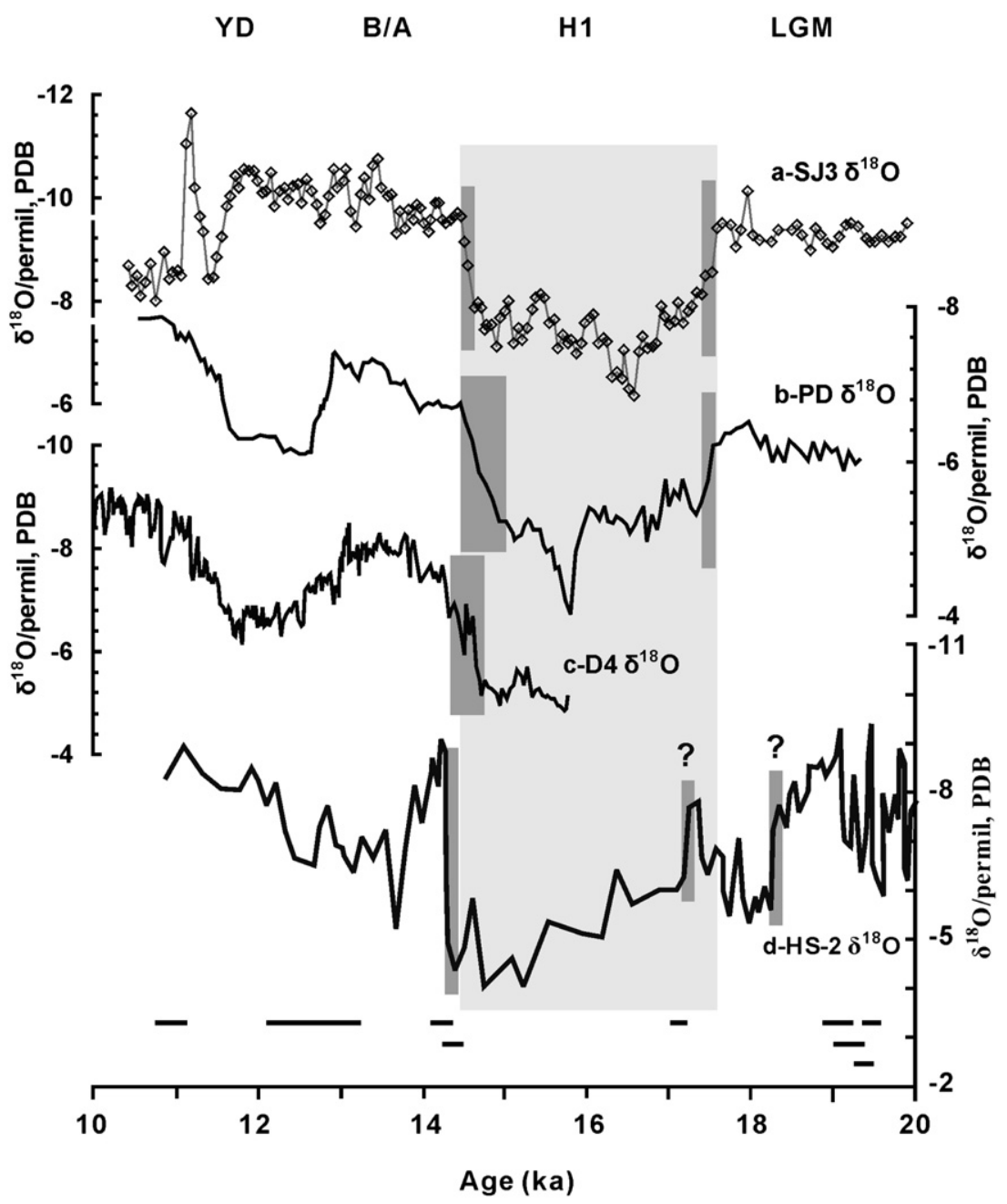

Figure 5. Comparison of the speleothem $\delta^{18} \mathrm{O}$ records from China. (a) The $\mathrm{SJ} 3 \delta^{18} \mathrm{O}$ record from Songiia Cave in Central China (this work). (b) The PD $\delta^{18} \mathrm{O}$ record from Hulu Cave in East China (Wang et al., 2001). (c) The D4 $\delta^{18} \mathrm{O}$ record from Dongge Cave in Southwest China (Yuan et al., 2004). (d) The HS-2 $\delta^{18} \mathrm{O}$ record from Heshang Cave in Central China (Hu et al., 2005). See Fig. 1 for the locations of these caves. The big light gray rectangle represents the H1 cold phase. The small dark gray rectangles indicate the transitions into and out of the $\mathrm{H} 1$ cold phase in each $\delta^{18} \mathrm{O}$ record. In the Heshang record (d), there are two possible correlations to the transition into the $\mathrm{H} 1$ cold phase which are indicated with question marks. As suggested in the text, this record needs more dates to constrain some important climatic events. Except the Heshang record, the $\mathrm{H} 1$ cold phase is similar in timing, duration and extent in the rest $\delta^{18} \mathrm{O}$ records. 
indicates that this transition took place within about $100 \mathrm{yr}$, from 14.6 to $14.5 \mathrm{ka}$; but the Hulu record suggests a longer transition of about $400 \mathrm{yr}$, from 14.9 to $14.5 \mathrm{ka}$ (Figs. 5a-b). This suggests that the recession of the H1 cold phase commences earlier in East China than in Central China. Considering that Songjia Cave is much more inland and close to the Mongolian high pressure and summer monsoon boundary relative to the Hulu and Dongge caves (Fig. 1), it is reasonable that this site be more resistant to the early recession of the $\mathrm{H} 1$ cold phase. This seems to be supported by sharp transition from the $\mathrm{H} 1$ cold phase to the $\mathrm{B} / \mathrm{A}$ warm period, within $\sim 100 \mathrm{yr}$, in both the SJ3 and GISP2 $\delta^{18} \mathrm{O}$ records (Figs. 4a, c). However, the slight difference in this transition among the three speleothem $\delta^{18} \mathrm{O}$ records (Figs. 5a-c) is not significant compared with the time shift of the warm Holocene optimum between coastal and inland China which is on the order of several thousands years (An et al., 2000; He et al., 2004). These may suggest that temperature change in the North Atlantic region exerts stronger influences on the Asian summer monsoon regime during glacial periods than during interglacial period.

The SJ3 $\delta^{18} \mathrm{O}$ record during the $\mathrm{H} 1$ cold phase is more than 2 $\%$ heavier than before or after this cold period (Fig. 5a). This is significant and is comparable with the $\delta^{18} \mathrm{O}$ enrichment in the Hulu and Dongge records during this cold event (Figs. 5b-c; Wang et al., 2001; Yuan et al., 2004; Dykoski et al., 2005). Considering that Songjia Cave is more than $1000 \mathrm{~km}$ west of Hulu Cave and $700 \mathrm{~km}$ north of Dongge Cave, and is much more close to the summer monsoon boundary (Fig. 1), the three speleothem $\delta^{18} \mathrm{O}$ records from the three caves (Fig. 5) may suggest a distinct and synchronous cold climatic phase over the whole of monsoonal China, associated with the H1 event identified in the North Atlantic sediments (Heinrich, 1988).

Based on the work on Hulu Cave in East China, Wang et al. (2001) suggested that changes in the East Asian summer monsoon were integral to millennial-scale changes in atmospheric/ oceanic circulation patterns and were affected by orbitallyinduced insolation variations. Although tropical oceans, especially the SW Pacific warm pool, have been suggested to be a potential forcing of the summer monsoon variation (Zhao et al., 2003) as it is an important moisture source for East Asia, the last deglaciation in this area appears to commence earlier than in continental China (Visser et al., 2003; Wang et al., 2001). Although for a large portion of the $\delta^{18} \mathrm{O}$ records from Hulu Cave, the long-term trend appears to follow summer (averaged over the months of June, July, and August) insolation at the cave $\left(33^{\circ} \mathrm{N}\right)$, variations after the LGM, seems to deviate significantly from this relationship (Wang et al., 2001). In addition, the SJ3 $\delta^{18} \mathrm{O}$ record is (2-3) \% lighter than the Hulu $\delta^{18} \mathrm{O}$ record despite their similar latitudes (Figs. 1 and $4 \mathrm{a}-\mathrm{b}$ ). The millennial-scale events after the LGM, especially the H1 cold phase is distinct and synchronous in the speleothem-based Asian summer monsoon records from different areas of China as well as in the GISP2 record (Figs. $4 \mathrm{a}-\mathrm{c}$ and $5 \mathrm{a}-\mathrm{c}$ ). This evidence suggests that during the last glacial period, the Asian summer monsoon was related more closely with temperature variations in northern high latitudes, compared with local insolation. The temporal relation between the polar Greenland $\delta^{18} \mathrm{O}$ record and the speleothem $\delta^{18} \mathrm{O}$ records over a wide range of continental China is consistent with North Atlantic events that trigger large-scale circulation changes during glacial periods (Broecker, 1994). Our results support the idea that millennial scale events first identified in Greenland are hemispheric or wider in extent (Broecker, 1994; Kienast et al., 2001). In the Asian summer monsoon regime, monsoonal rainfall and vegetation change rapidly and sensitively in parallel with deglacial temperature changes in the North Atlantic region, which is consistent with long-term histories of monsoon moisture, particularly those documented using the loess, lake and marine sediment records in China (Porter and An, 1995; Wang et al., 1999). The relationship between the summer monsoon and Greenland temperature may be maintained throughout the deglacial sequence and exists over almost the whole East Asian summer monsoon regime. However, this relationship may become less effective in the Holocene and thus the Holocene optimum shows a time shift of more than several thousands years from coastal to inland China (An et al., 2000; He et al., 2004).

\section{Conclusions}

The $\delta^{18} \mathrm{O}$ and $\delta^{13} \mathrm{C}$ records for stalagmite SJ3 collected from Songjia Cave in Central China provide new evidence for synchronous and significant climatic changes in China since the LGM, especially for the cold climatic phase associated with the H1 event, which is consistent with the GISP2 record from northern high latitudes. This is much different from the Holocene Optimum which shows a time shift of more than several thousands years from southeast coastal to inland China (An et al., 2000; He et al., 2004). Such rapid hemispheric synchronicity supports the role of atmospheric teleconnections between the North Atlantic and East Asia in controlling climate change throughout the Northern Hemisphere during the last deglaciation (Benson et al., 1997; Hendy and Kennett, 1999). Thus changes in air temperature in the North Atlantic region appear to be associated with altered large-scale atmospheric/oceanic circulation patterns in the Northern Hemisphere during glacial periods, with implications for monsoonal rainfall and paleovegetation in East Asia. It is likely that during glacial periods, temperature change in northern high latitude exerts a stronger influence on the Asian summer monsoon relative to insolation, and that climatic signals in the North Atlantic region propagate rapidly to East Asia by influencing the winter land-sea temperature contrast in the East Asian monsoon region (Porter and An, 1995).

\section{Acknowledgments}

The research is financially supported by the project of NNSFC (40672120), the Pilot Project of Chinese Academy of Sciences (KZCX3-SW-152), key project of NNSFC (40331009), the Key Laboratory of Marginal Sea Geology, CAS (No. GIGCX-04-01) and the Australian Research Council (LP0453664). Thanks are also due to Dr. Dingchuang Qu and Joseph A. Cali for their help with oxygen and carbon isotope analysis, and to Mr. Huang Jie and $\mathrm{Wu}$ Zheng for their help in sample collection. 


\section{References}

An, Z.S., Porter, S.C., Kutzbach, J.E., Wu, X.H., Wang, S.M., Liu, X.D., Li, X.Q., Zhou, W.J., 2000. Asynchronous Holocene optimum of the East Asian monsoon. Quaternary Science Reviews 19, 743-762.

Araguas-Araguas, L., Froehlich, K., 1998. Stable isotope composition of precipitation over southeast Asian. Journal of Geophysical Research 103 (D22), 28721-28742.

Baker, A., Ito, E., Smart, P.L., McEwan, R.F., 1997. Elevated and variable values of $\mathrm{C}-13$ in speleothems in a British cave system. Chemical Geology 136, 263-270.

Banner, J.L., Musgrove, M., Asmerom, Y., et al., 1996. High-resolution temporal record of Holocene ground-water chemistry: tracing links between climate and hydrology. Geology 24, 1049-1052.

Baskaran, M., Krishnamurthy, R.V., 1993. Speleothems as proxy for the carbon isotope composition of atmospheric $\mathrm{CO}_{2}$. Geophysical Research Letters 20, 2905-2908.

Beck, J.W., Recy, J., Taylor, F., Edwards, R.L., Cabioch, G., 1997. Abrupt changes in early Holocene tropical sea surface temperature derived from coral records. Nature 385, 705-707.

Benson, L., Burdett, J., Lund, S., Kashgarian, M., Mensing, S., 1997. Nearly synchronous climate change in the Northern Hemisphere during the last glacial termination. Nature 388, 263-265.

Broecker, W.S., 1994. Massive iceberg discharges as triggers for global climate change. Nature 372, 421-424.

Bureau of Geology and Mineral Resources of Sichuan Province, 1991. Regional Geology of Sichuan Province. Geological Publishing House, Beijing.

Cao, J., Yang, J.Y., 2005. Characteristics of Geological Vestiges Landscape in the Nuoshuihe Geopark, Sichuan. Geological Acta of Sichuan Province, vol. 25 (2) (in Chinese with English abstract).

CLIMAP Project Members, 1976. The surface of the ice-age earth. Science 191, $1131-1137$

Dansgaard, W., 1964. Stable isotopes in precipitation. Tellus 16, 436-468.

Dorale, J.A., Edwards, R.L., Ito, E., Gonzàlez, L.A., 1998. Climate and vegetation history of the midcontinent from 75 to $25 \mathrm{ka}$ : a Speleothem record from Crevice Cave, Missouri, USA. Science 282, 1871-1874.

Dykoski, C.A., Edwards, R.L., Cheng, H., Yuan, D., Cai, Y., Zhang, M., Lin, Y., Qin, J., An, Z., Revenauh, J., 2005. A high-resolution, absolute-dated Holocene and deglacial Asian monsoon record from Dongge Cave, China. Earth and Planetary Science Letters 233, 71-86.

Fleitmann, D., Burns, S.J., Neff, U., Mudelsee, M., Mangini, A., Matter, A., 2004. Palaeoclimatic interpretation of high-resolution oxygen isotope profiles derived from annually laminated speleothems from Southern Oman. Quaternary Science Reviews 23, 935-945.

Gascoyne, M., 1992. Palaeoclimate determination from cave calcite deposits. Quaternary Science Reviews 11, 609-632.

Genty, D., Blamart, D., Ouahdi, R., Gilmour, M., Baker, A., Jouzel, J., van Exter, S., 2003. Precise dating of Dansgaard-Oeschger climate oscillations in western Europe from stalagmite data. Nature 421, 833-837.

Grootes, P.M., Stuiver, M., White, J.W.C., Johnsen, S., Jouzel, J.J., 1993. Comparison of oxygen isotope records from the GISP2 and GRIP Greenland ice cores. Nature 366, 552-554.

He, Y., Theakstone, W.H., Zhonglin, Z., Dian, Z., Tandong, Y., Tuo, C., Yongping, S., Hongxi, P., 2004. Asynchronous Holocene climatic change across China. Quaternary Research 61, 52-63.

Heinrich, H., 1988. Origin and consequences of cyclic ice rafting in the Northeast Atlantic Ocean during the past 130,000 years. Quaternary Research 29, 142-152.

Hendy, C.H., 1971. The isotopic geochemistry of speleothems 1. The calculation of the effects of the different modes of formation on the isotopic composition of speleothems and their applicability as palaeoclimatic indicators. Geochimica et Cosmochimica Acta 35, 801-824.

Hendy, C.H., Wilson, A.T., 1968. Palaeoclimatic data from speleothem. Nature 216, 48-51.

Hendy, I.L., Kennett, J.P., 1999. Latest Quaternary North Pacific surface-water responses imply atmosphere-driven climate instability. Geology 27, 291-294.

Holmgren, K., Karlén, W., Shaw, P.A., 1995. Paleoclimatic significance of the stable isotopic composition and petrology of a late Pleistocene stalagmite from Botswana. Quaternary Research 43, 320-328.
Hu, C.-Y., Huang, J.-H., Fang, N.-Q., et al., 2005. Adsorbed silica in stalagmite carbonate and its relationship to past rainfall. Geochimica et Cosmochimica Acta 69, 2285-2292.

Ijiri, A., Wang, L., Oba, T., Kawahata, H., Huang, C.-Y., Huang, C.-Y., 2005. Paleoenvironmental changes in the northern area of the East China Sea during the past 42,000 years. Palaeogeography, Palaeoclimatology, Palaeoecology 219, 239-261.

Johnson, K.R., Ingram, B.L., Sharp, W.D., et al., 2006. East Asian summer monsoon variability during Marine Isotope Stage 5 based on speleothem $\delta^{18} \mathrm{O}$ records from Wanxiang Cave, central China. Palaeogeography, Palaeoclimatology, Palaeoecology 236, 5-19.

Jouzel, J., Lorius, C., Petit, J.R., et al., 1987. Vostok ice core: a continuous isotope temperature record over the last climatic cycle (160000 years). Nature 329, 403-408.

Kienast, M., Steinke, S., Stattegger, K., Calvert, S.E., 2001. Synchronous tropical South China Sea SST change and Greenland warming during deglaciation. Science 291, 2132-2134.

Kim, S.T., O’Neil, J.R., 1997. Equilibrium and nonequilibrium oxygen isotope effects in synthetic carbonates. Geochimica et Cosmochimica Acta 61, 3461-3475.

Kucera, M., Weinelt, M., Kiefer, T., et al., 2005. Reconstruction of sea-surface temperatures from assemblages of planktonic foraminifera: multi-technique approach based on geographically constrained calibration data sets and its application to glacial Atlantic and Pacific Oceans. Quaternary Science Reviews 24, 951-998.

Liu, T.S., Ding, Z.L., 1998. Chinese loess and the paleomonsoon. Annual Review of Earth and Planetary Sciences 26, 111-145.

Martinson, D.G., Pisias, N.G., Hays, J.D., Imbrie, J., Moore Jr., T.C., Shackletion, N.J., 1987. Age dating and the orbital theory of the ice ages: Development of a high-resolution 0 to 300000-year chronostratigraphy. Quaternary Research 27, $1-29$.

McDermott, F., 2004. Palaeo-climate reconstruction from stable isotope variations in speleothems: A review. Quaternary Science Reviews 23, 901-918.

Porter, S.C., An, Z.S., 1995. Correlation between climate events in the North Atlantic and China during last glaciation. Nature 375, 305-308.

Rozanski, K., 1985. Deuterium and Oxygen-18 in European Groundwaters-Links to Atmospheric circulation in the past. Chemical Geology 52, 349-363.

Rozanski, K., Araguás-Araguás, L., Gonfiantini, R., 1992. Relation between long-term trends of Oxygen-18 isotope composition of precipitation and climate. Science 258, 981-985.

Rozanski, K., Araguás-Araguás, L., Gonfiantini, R., 1993. Isotopic patterns in modern global precipitation. In: Swart, P.K., Lohmann, K.C., Savin, McKenzie L. (Eds.), Climate changes in continental isotopic records. Geophysical Monograph, vol. 78. American Geophysical Union, Washington DC, pp. 1-36.

Schwarcz, H.P., 1986. Geochronology and isotopic geochemistry of speleothems. In: Fritz, P., Fontes, J.Ch. (Eds.), Handbook of Environmental Isotope Geochemistry. Elsevier, Amsterdam, pp. 271-303.

Shao, X.H., Wang, Y.J., Cheng, H., Kong, X.G., Wu, J.Y., 2006. Holocene monsoonal climate and arid events recorded by a stalagmite from Shenlongjia, Hubei Province. Chinese Science Bulletin 51, 80-86 (in Chinese).

Shi, Y.F., Kong, Z.C., Wang, S.M., Tang, L.Y., Wang, F.B., Chen, Y.D., Zhao, X.T., Zhang, P.Y., Shi, S.H., 1992. Basic feature of climates and environments during the Holocene Megathermal in China. Science in China. Series B, Chemistry, Life Sciences \& Earth Sciences 35, 1300-1308 (in Chinese).

Sinomaps Press, 1984. Atlas of the People's Republic of China. Sinomaps Press, Beijing.

Spötl, C., Fairchild, I.J., Tooth, A.F., 2005. Cave air control on dripwater geochemistry, Obir Caves (Austria): Implications for speleothem deposition in dynamically ventilated caves. Geochimica et Cosmochimica Acta 69, 2451-2468.

Stuiver, M., Grootes, P.M., Braziunas, T.F., 1995. The GISP2 delta 180 climate record of the past 16,500 years and the role of the sun, ocean, and volcanoes. Quaternary Research 44, 341-354.

Tan, M., Cai, B.G., 2005. Preliminary Calibration of Stalagmite Oxygen Isotopes from Eastern Monsoon China with Northern Hemisphere Temperatures. Pages Newsletter 13 (2), 16-17.

Thompson, L.G., Yao, T.D., Davis, M.E., Henderson, K., Mosley-Thompson, A.E., Lin, P.-N., Beer, J., Synal, H.-A., Cole-Dai, J., Bolzan, J.F., 1997. Tropical 
climate instability: the last glacial cycle from a Qinghai-Tibetan ice core Science 276, 1821-1825.

Visser, K., Thunell, R., Stott, L., 2003. Magnitude and timing of temperature change in the Indo-Pacific warm pool during deglaciation. Nature 421, 152-155.

Wang, L.J., Sarnthein, M., Erlenkeuser, H., Grimalt, J., Grootes, P., Heilig, S., Ivanova, E., Kienast, M., Pelejero, C., Pflaumann, U., 1999. East Asian monsoon climate during the Late Pleistocene: high-resolution sediment records from the south China Sea. Marine Geology 156, 245-284.

Wang, Y.J., Cheng, H., Edwards, R.L., An, Z.S., Wu, J.Y., Shen, C.C., Dorale, J.A., 2001. A high-resolution absolute-dated late Pleistocene monsoon record from Hulu Cave, China. Science 294, 2345-2347.

Webster, J.W., Brook, G.A., Railsback, L.B., et al., 2007. Stalagmite evidence from Belize indicating significant droughts at the time of Preclassic Abandonment, the Maya Hiatus, and the Classic Maya collapse. Palaeogeography, Palaeoclimatology, Palaeoecology 250, 1-17.

Wigley, T.M.L., Brown, M.C., 1976. The physics of caves. In: Ford, T.D., Cullingford, C.H.D. (Eds.), The Science of Speleology. Academic Press, London, pp. 329-358.

Winograd, I.J., Szabo, B.J., Coplen, T.B., Riggs, A.C., Kolesar, P.T., 1985. Twomillion-year record of deuterium depletion in Great Basin ground waters. Science, 227, 519-522.
Yuan, D.X., Cheng, H., Edwards, R.L., et al., 2004. Timing, Duration, and Transitions of the Last Interglacial Asian Monsoon. Science 304, 575-578.

Zhang, X.P., Yao, T.D., 1998. Distributional features of $\delta^{18} \mathrm{O}$ in precipitation in China. Acta Geographica Sinica 53 (4), 356-364 (in Chinese with English abstract).

Zhao, J.X., Hu, K., Collerson, K.D., et al., 2001. Thermal ionization mass spectrometry U-series dating of a hominid site near Nanjing, China. Geology $29,27-30$.

Zhao, J.X., Wang, Y.J., Collerson, K.D., Gagan, M.K., 2003. Speleothem U-series dating of semi-synchronous climate oscillations during the last deglaciation. Earth and Planetary Science Letters 216, 155-161.

Zhou, H.Y., 2002. A Comment on "Tree-Ring $\delta \mathrm{D}$ as an indicator of Asian Monsoon intensity". Quaternary Research 58, 210-211.

Zhou, H.Y., Li, T.G., Jia, G.D., Zhu, Z.Y., Chi, B.Q., et al., 2007. Sea Surface Temperature Reconstruction for the Middle Okinawa Trough during the Last Glacial-Interglacial Cycle Using C37 Unsaturated Alkenones. Palaeogeography, Palaeoclimatology, Palaeoecology 246, 440-453.

Zhou H.Y., Feng Y.X., Zhao J.X., Zhu Z.Y., Chi B.Q., et al., in preparation. Strontium contents and isotopic ratios of a stalagmite from Central China and their paleoclimatic implications. 